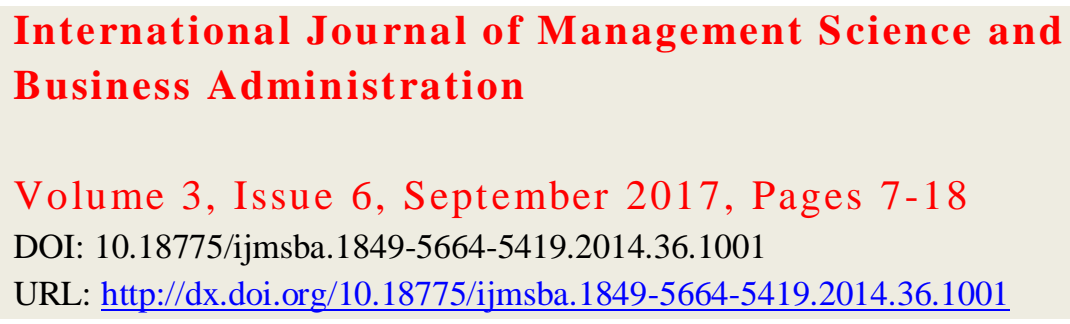

\title{
The Entry Process of Higher Education Institutions in Brazil: The Case of Laureate International Universities
}

\author{
${ }^{1}$ Renato Márcio Bulgarão, ${ }^{2}$ George Bedinelli Rossi, ${ }^{3}$ Rony Locher \\ ${ }^{12} 3$ ESPM, School of Arts, Sciences and Humanities, University of Sao Paulo, Sao Paulo, Brazil
}

\begin{abstract}
This research aims to investigate the entry process of higher education institutions in Brazil, in particular the case of Laureate International Universities. To do so, Cultural, Administrative, Economic and Geographic distances CAGE Framework - were used and which of these distances has more importance in this entry process. A single case study was carried on. Data was collected by interviews, newspapers, and documents. Content analysis was done by grouping convergent ideas on dendrograms (trees words) which were evaluated 17 key terms to elucidate this research. The survey showed that in the case of Laureate international universities the cultural, administrative, geographic and economic distances influenced partially the entry process. Regarding all distances, Cultural is the most important mainly the language and religion which imposes very different norms and behavior for conducting business and personal relationship. A second distance that has impact is Administrative, concerning with currency instability as inflation, and for economic distance, infrastructure differences is the most important point.
\end{abstract}

Keywords: Higher education, CAGE Model, Internationalization, Laureate Universities, Entry Process

\section{Introduction}

In accordance with the World Bank Group (2016), in the 1998-2014 period, as the economies in developed countries entered into the stage of maturity and showed lower negative growth rates, countries or emerging economies had great potential for grow than do economic development. Wilson and Purushothaman (2003) estimate that by 2035, the gross national product of developing countries permanently will exceed all the developed and advanced countries.

Sheth (2011) stated that there are several factors which are responsible for the growth of emerging markets. First, economic reforms in Brazil, Russia, India and China have unlocked their markets protected by ideology and socialism. Second, the developed countries are aging rapidly, which implies in stagnation of its markets or slow growth. Third, the global liberalization of trade and investment, bilateral trade agreements, economic and regional integration as ASEAN, Mercosur and the European Union have resulted in global competition and global unprecedented product and services offerings, especially in emerging markets. And finally, the birth of a new middle class, especially in large markets such as China, India and Brazil for the first time, creates a large-scale market for various products and services.

Thus, while developed countries show low growth rates (Lamy, 2006), firms looking to expand are turning to the emerging markets in order to make profits (O'Reilly 1988; Peak 1992; Goetzmann and Jorion 1999) .Prahalad and Hart (2002) argue that markets with the greatest potential stand on the billions of poor people who are entering the Market consumption for the first time, a view that goes together with Merrilees (2014) for whom 80 percent of the world population lives in what is called or emerging markets countries.

But markets with greater potential for big returns have high risks (Amin, Sanusi, Kusairi, and Abdallah, 2014), and emerging markets are no exception. The problems with these markets are importante to be considered by companies in developed markets which intend to entering to the emerging ones. Some of these problems are communications infrastructure (Khanna and Palepu, 1997), financial markets relatively under developed, economic volatility, difficulty 
in finding business partners (Hitt, Tina, Dancin, Levitas, Arreggle, and Borza, 2000) and corruption (Khanna, Palepu and Singh, 2005).

Johnson and Tellis (2008) argue that these problems create distances between emerging and developed markets, with which companies must adapt it selfs. Ghemawat (2001), Miller (1992), Luostarinen (1979) and Dow and Karunaratna (2006) emphasize that costs and risks related to the various distances of non-business (non-business) between these markets need to be recognized. Ghemawat (2001) proposes to consider the distances (C) Cultural (A) Administrative (G) Geographicand (E), CAGE model for the analysis of the distances between markets that will be the theoretical basis for this research.

Thus, the research problem was: What factors in fluence the process of entering of a higher education institution in Brazil? The phenomenon under investigation is the process of internationalization and the case is the Laureate (Schwandt, 1994/2006) and the overall objective is to verify the importance of the distances. - Culture, Administration, Geographic and Economic - at the entrance of the Laureate international network in Brazil.

\section{Literature Review}

Harris and Wheeler (2005) define internationalization as a process in which the company sells its products or services outside their local Market or source, thus focusing their involvemental so in external markets. According to Welch and Luostarinen (1988), internationalization is the process where the company increases involvement in the cross-borde roperations. It is a process through which the company operates outside its home Market and thus the internationalization can be understood from diferente way so facting abroad, ranging from in direct export, joint ventures, licensing and acquisitions up to foreign direct investment (Root, 1994).

According to Cavusgil (2010), companies seek internationalization for some reasons and often these reasons are not isolated, some of them are strategic in nature and other reactives. In the case of internationalization of higher education we can mention some of them: look for growth opportunities through diversification, due to a significant potential market outside of the country of origin; Get higher profit margins, where as foreign markets which may be under served; Acquire new ideas about, services and forms of trading, giving the company's exposure to new ideas about processes and methods in outdoors enviroments; Develop economies of scale in this case in marketing and R \& D due to a reduction in unit costs resulting from added volumes; Facing international competition effectively or frustrate the growth of competition in the domestic market, improving the competitive position to face international competition; Invest in a potentially advantageous relationship with a foreign partner, this can lead to the development of new products and services (Moja, 2004).

The globalization poses challenges for regional and national systems of higher education in the world of internationalization (Moja, 2004) that must be solved through business strategies. Hayhoe (1989), believes that international cooperation agreements, academic mobility, international scholarships, technical and economic development, international curriculum studies, cultural, historical and political context are the most importante reasons for the internationalization of higher education.

\subsection{Cage Framework - Measuring Distance Between Countries}

One way to assess the internationalization process is the CAGE model. Ghemawat (2001), developed the CAGE model, in order to take into account, the cultural, administrative, geographic and economic distance between focal nation and another or more, and often, the managers prioritize only cost aspects and risk when they decide to internationalize a particular country. In addition to these aspects, the sales potential should also be part of this analysis and the sum of these factors, come from four aspects of distance between the countries, called by Ghemawat (2008) cultural, administrative, geographic and economics.

\subsubsection{Cultural Distance}

Cultural distance has its roots in the work of Hofstede (1980) which analyzed IBM's operations in 40 countries in the period 1967-1973 by identifying the dimensions 'distance power', 'risk aversion', 'individualism' and 'masculinity' (Drogendijk and Slangenm, 2006). Among many authors who criticized the results of Hofstede, there is Schwartz (1994) for those who have not examined the cultures of countries but IBM employees who do not necessarily represent countries 
or there was a sample of countries covering the entire spectrum of national cultures; and the findings may be obsolete since culture is dynamic and may have changed from the time of the survey to the present day.

About the application of culture in international business there is the concept of the Cultural Distance considered complex, intangible, subtle and difficult to be respected and of have scales (Boyacigiller, Kleinberg, Philips, and Sackmann, 1996). Kogut and Singh (1988) to create a simple and standardized measure to measure cultural distance, they created a tangible and convenient tool to deal with the complexities of this construct. For Shenkar (2001) the Cultural constructo is illusory do to the conceptualizing problems and measure, ranging from hidden assumptions to questionable methodologies undermining thus, the validity and challenging their theoretical and application role.

Shenkar (2001) asserts that although Cultural Distance has the criticism above cited, its application in research of foreign investment over the past 50 years has been broad, with strong emphasis on the work of Kogut and Singh (1988) and Hofstede (1980), and Drogendijk and Slangenm (2006) include Schwartz (1994).

About the importance of Cultural Distance, De Mooij (2004) asserts that the dimensions of culture exert greater influence in consumption patterns rather than the economic laws. Culture defined as values and meanings shared by members of a society affects both the consumption pattern and the implementation and execution of strategies (Kogut and Singh, 1988) implying its importance in entry strategies. This vision is shared by Håkanson and Ambos (2010) for whom the cultural distance between countries is defined as the distance between the source and the target market is determined by the perception of differences in religious beliefs, races, social norms and languages. In this work, to adopt these differences.

\subsubsection{Administrative Distance}

The administrative distance (A) involves aspects of being a member of the same union of countries, eg Commonwealth Countries, or part of a block of free trade as North AmericaFree Trade Area (NAFTA), European Union (EU) and MERCOSUR. It can be argued that this factor is a facilitator between the international list of countries, as this is an aspect of great impact in the process of destination country (Andersson and Lundströn, 2007). This distance can be increased with trade barriers such as high import taxes, or rigid standards of quality and product safety. Countries with high levels of corruption and social conflicts suffer a negative impact on economic development (Ghemawat, 2008).

It is included in the results of Administrative Distance from Kostova and Roth (2008) and Xu and Shenkar (2002) for anyone considering the institutional distance between countries as an important factor. It is defined Institutional distance as the difference in the aspects of regulation, cognition and standards between the country and the destination of origin. Berry, Guillén, and Zhou (2010) complement this distance with bureaucracy, colonial ties, legal systems and political stability. And, Campbell, Eden, and Miller (2012) complement with formality, political systems (democracy vs. dictatorship) and the influence of the government in the business environment.

\subsubsection{Geographical Distance}

The geographic distance $(G)$, would not be only measured by the distance in kilometers, but the extent and access to the country by water and land, as well as the infrastructure in transport and telecommunications. These aspects also influence the operating cost and the speed of transport products. Even communication infrastructure between multinational banks for example, and telephone traffic, can influence the distance factor between countries (Andersson and Lundströn, 2007). Geographical distance generally is confused with the Cultural (Shenkar, 2001) reducesentry barriers (Chao, and Kumar, 2010) due to the procedures of transport and information. The geographical distance reduces coordination costs and control as well as the intermediation costs. Facilitates personal contacts that are needed for transactions (Vachani, 1991).

Kuo and Fang (2009) assert that the level of information infrastructure, measured by the telephone traffic and the number of branches of multinational banks can influence the physical distance and the flows either of physical assets as well as the intangibles. Large differences in supply chains and distribution channels can mean significant barriers to business. Larger geographical distances imply higher cost due to the extensive distribution system which includes the transport modes (aircraft, trucks, trains), storage of goods and retail; all these activities can result in high costs (Kuo and Fang, 2009).

\subsubsection{Economic Distance}

The Economic Distance factor (E), should also be analyzed. This aspect emphasizes that companies that rely on their 
economies of scale model, standardization and experience, have a greater tendency to move toward markets with similar characteristics (Ghemawat, 2008). When the cost and the quality of available resources and even the average income of consumers is far from those found in the home country, companies end up encountering difficulty of success. On the other hand, there are companies that make the distances aspects in its own favor, establishing differentiated prices and practices for each market (Andersson and Lundströn, 2007).

Differences in economic conditions are important because many companies emphasize countries with economic similarities to do business on the grounds that this implies little change in their strategies due to the similarities of market segments and product acceptance (Kuo and Fang, 2009). On the other hand, less developed countries companies have the preference to do business with developed countries by realizing greater profits opportunity (Kuo and Fang, 2009). Jain (1989) asserts that economically similar countries reflect income as well as similar life styles. Thus, similar income influence strategies for the launches of products, pricing and communication strategies (Baalbaki and Malhotra, 1993).

\section{Methodology}

To investigate the process of internationalization of higher education, we used the method of qualitative research type unique case study (Creswell, 2010; Cesar, 2005; Eisenhardt, 1989) as well as intensive as proposed by Swanborn (2010) and Hodgetts and Stolte (2012). The corpus of this research is based on the guidelines of Bauer and Aarts (2002), namely: relevant topics considering the issue of research and data collection, within a given time cycle.

\subsection{Sample and Data Collection}

The sample was theoretical (Suri, 2011) comprising collecting data and information in three (03) newspaper (Folha de São Paulo, Valor Econômico, Industry Trade Journal), in official documents as ACN (Agency Board News) SEMESP (Union of Entities Maintainers of Higher Education Institutions), CADE and business contracts filed at JUCESP from 2013 to 2015 and other such which INEP (2014), LaureateEducation (2015), KPMG (2004), Alwan (2014) and Zogby Analytcs (2014).

As for the selection of respondents for personal interviews we opted for purposeful and representative sample of the FMU and UAM totalizing 07 respondents which is for Tuli (2007), and Rabiee (2004) enough to the saturation. Three requirements in the selection of the respondents were: to know the higher education institution before and after the time of acquisition; be an official of the higher education institution at the time of acquisition; and have professional practice in teaching the segment for a period exceeding ten years and may be in the institutions addressed here or in other institutions. The names of the respondents were lied confidential as agreed in the interview consent. The following table presents the characteristics of respondents whose testimony formed the corpus of this research.

Table 1: Interviewed list

\begin{tabular}{|c|c|c|c|}
\hline$\#$ & Denomination & Hierarchical Profile & IHE \\
\hline 1 & E1 & Member of Board of Directors & UAM \\
\hline 2 & E2 & Member of Board of Directors & UAM \\
\hline 3 & E3 & Member of Board of Directors & FMU \\
\hline 4 & E4 & Manager & FMU \\
\hline 5 & E5 & Manager & FMU \\
\hline 6 & E6 & Member of Board of Directors & UAM \\
\hline 7 & E7 & & \\
\hline
\end{tabular}

Source: The authors - IHE: institution of higher education; UAM: Universidade Anhembi Morumbi: FMU: Faculdades Metropolitanas Unidas.

For the interviews was used an unstructured scrip in order to encourage the interviewees to speak spontaneously as proposed by Kvale (2008) which is presented below. 
Table 2: Interview Script

\begin{tabular}{|c|}
\hline $\begin{array}{l}\text { Cultural Distance-Question 1: There is evidence that the language differences between countries influence } \\
\text { in some processes of international negotiations. How the language difference interfered in the } \\
\text { internationalization process Laureate in view of the case of the acquisition of (FMU or UAM as the } \\
\text { respondent)? }\end{array}$ \\
\hline $\begin{array}{l}\text { Cultural Distance-Question 2: There is evidence that the difference in cultural values between countries } \\
\text { influence in some processes of international negotiations. How the difference in cultural values between } \\
\text { countries interfered in the internationalization process Laureate in view of the case of the acquisition of } \\
\text { (FMU or UAM as the respondent)? }\end{array}$ \\
\hline $\begin{array}{l}\text { Administrative Question 3: There is evidence that the difference in cultural values within organizations } \\
\text { influence in some processes of international negotiations. How the difference in cultural values within } \\
\text { organizations interfered in the internationalization process Laureate in view of the case of the acquisition } \\
\text { of (FMU or UAM as the respondent)? }\end{array}$ \\
\hline $\begin{array}{l}\text { Economic Distance - Question 4: There is evidence that the lack of economic blocs between countries } \\
\text { influence in some processes of international negotiations. How the lack of economic blocs between Brazil } \\
\text { and the US interfered in the internationalization process Laureate in view of the case of the acquisition of } \\
\text { (FMU or UAM as the respondent)? }\end{array}$ \\
\hline $\begin{array}{l}\text { Economic Distance-Question 5: There is evidence that the currency difference (exchange, currency } \\
\text { credibility) influence in some processes of international negotiations. How the difference between coins } \\
\text { interfered in the internationalization process Laureate in view of the case of the acquisition of (FMU or } \\
\text { UAM as the respondent)? }\end{array}$ \\
\hline $\begin{array}{l}\text { Economic Distance -Question 6: There is evidence that the difference in human resources (people's ability } \\
\text { to ensure the viability of the company's productive process) between countries influence in some processes } \\
\text { of international negotiations. How the difference between the human resources interfered in the } \\
\text { internationalization process Laureate in view of the case of the acquisition of (FMU or UAM as the } \\
\text { respondent)? }\end{array}$ \\
\hline $\begin{array}{l}\text { Geographic Distance -Question 7: How you see coming to Brazil and/or having communications with } \\
\text { Brazil? }\end{array}$ \\
\hline
\end{tabular}
Source: The Authors

\section{Result and Discussion}

\subsection{Result}

After collecting data / information from newspaper reports, documents and interviews it was made use of semantic content analysis (Olabuenaga and Ispizua, 1989) in which the data were organized and synthesized and categorized then to obtain relevant to the general objective of this research (Strijbos, Martens, Prins, and Jochems 2006). Then we tested the consistency and category codes for 03 different researchers. For validation, we adopted the suggestions of Watt (2007), namely, internal validity and interpretation and integrity. And, for the convergence of evidence in order to avoid misinterpretation was made use of documents and letters, journalistic and advertising material and interviews as exposed by Creswell and Miller (2000), Golafshani (2003). The data were analyzed using the QSR NVIVO 10 TM for Windows software.

To analyze the data through content analysis was made using dendograms that results from statistical analysis of the data by creating clusters and their ascending hierarchical ordering showing how clusters are formed: by bringing together two individual observations or pairing a single observation with a grouping existing. You can see at what level of similarity the clusters are formed, and the composition of the final partition groups (Guha, Rastogi, and Shim, 2001).

By analyzing the content of the various categories, through dendograms, we investigated the connotations associated with each of them and the joints and discontinuities between the categories of information. different correlations and associations were examined between categories, to detect the logic of emerging thread in the process. This content analysis technique did the term come naturally (emerging categories), the term that was not pointed in the column ambivalence or convergence, not emerged so it was not relevant to the response of respondents since they did not mention the terms. 
Emerging categories may have two components or values in opposite directions or not (ambivalence or confusion) with its simple pointing and counting (Bardin, 2011). Among the desirable characteristics of the rules to be followed in the grouping of elements that form the emerging categories of work on the data, listed by Bardin (2011) and guiding the fragmentation of texts (communication).

Next we see the emerging categories checked in hierarchical dendograms for each term analysis, involving the input process of higher education institutions to Brazil .At the group some of the aspects of "culture" according to the CAGE Framework Ghemawat (2001) and then apply the convergences (ambivalence) and differences (confusion) according to Bardin (2011,) that were found in dendogramms was possible to draw up the following table illustrating the emerging categories for the aspect "culture" in the process of internationalization of Laureate international network for Brazil.

Table 3: Emerging categories identified in the dendrogram for the cultural distance and its aspects

\begin{tabular}{|c|c|c|}
\hline Analysed Term & Ambivalence or Convergence (emerging category) & $\begin{array}{c}\text { Confusion } \\
\text { (divergence of ideas) }\end{array}$ \\
\hline Culture & Culture change & N/F \\
\hline Trust & Trust and quality increase & No interference \\
\hline Language & Easiness & N/F \\
\hline Norms & N/E & N/F \\
\hline Standards & Strategic implementation & N/F \\
\hline Social & N/E & \\
\hline
\end{tabular}

Source: The authors $-\mathrm{N} / \mathrm{F}=$ Not found

By checking the above box, we see the emerging categories of some aspects of "culture", it appears the content proposing the following ideas: Convergences: Culture change with increase of gradual confidence to standards and estratégicas. Divergências deployments: There are indications that the language between countries difficult if is different or easy if is the same, there are founds in the content that indicate that the language does not interfere.

Table 4: Emerging categories identified in dendogramas for administrative distance and its aspects

\begin{tabular}{|c|c|c|}
\hline Analysed Term & Ambivalence or Convergence (emerging category) & $\begin{array}{c}\text { Confusion } \\
\text { (divergence of ideas) }\end{array}$ \\
\hline Management & Improvement, improvement, skills & Increased costs, difficulties \\
\hline Blocks & $\mathrm{N} / \mathrm{F}$ & $\mathrm{N} / \mathrm{F}$ \\
\hline Bureaucracy & $\mathrm{N} / \mathrm{F}$ & $\mathrm{N} / \mathrm{F}$ \\
\hline Currency & Instability, uncertainty & $\mathrm{N} / \mathrm{F}$ \\
\hline Politics & Implementation & \\
\hline
\end{tabular}

Source: The authors - N/F = Not found

The terms "standards" and "social" did not emerge and therefore did not appear in a convergent manner sample. The terms "standards" and "social" were not relevant to the response of respondents viewed that they did not mention the terms.

By grouping some aspects of "administrative" according to the CAGE Framework from Ghemawat (2001) and then apply the convergences (ambivalence) and differences (confusion) according to Bardin (2011) that were found in dendogramms. It was possible prepare the following table illustrating the emerging categories for the aspect "administrative" in the process of internationalization of international Laureate network for Brazil.

By checking the box above, we see the emerging categories of some aspects of the "administrative", it appears the content proposing the following ideas: Convergences: need for improvement in the management and improvement of skills. Divergence: nothing found. The terms "blocks" and "bureaucracy" did not emerge and therefore did not appear in a 
convergent manner sample. The terms "blocks" and "bureaucracy" were not relevant to the response of respondents viewed that they did not mention the terms.

By grouping some aspects of the "geographical" according to the CAGE Framework from Ghemawat (2001) and then apply the convergences (ambivalence) and differences (confusion) according to Bardin (2011) that were found in their dendagramas, it was possible prepare the following table illustrating the emerging categories for the aspect "geographical" in the process of internationalization of international Laureate network for Brazil.

Table 5: Emerging categories Identified in dendagramas to geographical distance and its aspects

\begin{tabular}{|c|c|c|}
\hline Analysed Term & Ambivalence or Convergence (emerging category) & $\begin{array}{c}\text { Confusion } \\
\text { (divergence of ideas) }\end{array}$ \\
\hline Geographical & commercial rivalry by region & N/F \\
\hline Climate & N/F & N/F \\
\hline
\end{tabular}

Source: The authors - N/F = Not found

By checking the box above, we see the emerging categories of some aspects of the "geographical" content proposing the following ideas are there: Convergences: commercial rivalry by region. Divergence: Nothing found.

The term "climate" did not emerge and therefore did not appear in a convergent manner sample. The term "climate" was also not relevant to the response of respondents viewed that they did not mention the term. By grouping some aspects of the "economic" according to the CAGE Framework from Ghemawat (2001) and then apply the convergences (ambivalence) and differences (confusion) according to Bardin (2011) that were found in their dendagramas, it was possible prepare the following table illustrating the emerging categories for the aspect "economic" in the process of internationalization of international Laureate network for Brazil.

Table 6: Emerging categories identified in dendagramas for economic distance and its aspects

\begin{tabular}{|c|c|c|}
\hline Analysed Term & Ambivalence or Convergence (emerging category & $\begin{array}{c}\text { Confusion } \\
\text { (divergence of ideas) }\end{array}$ \\
\hline Economy & Improves Growth performance & N/F \\
\hline Financial & Quality of returns, Benefits & N/F \\
\hline Infrastructure & Modern, differentiated improvements & N/F \\
\hline Resources & N/F & \\
\hline
\end{tabular}

Source: The authors - N/F = Not found

By checking the box above, we see the emerging categories of some aspects of the "economic", it appears the content proposing the following ideas: Convergences: Improving at economic performance in different infrastructure. Divergence: Nothing found.

The term "resources" not emerged and so did not appear in a convergent manner sample. The term "resources" was also not relevant to the response of respondents viewed that they did not mention the term.

\subsection{Discussion}

This research dealt with the entry process of higher education institutions in Brazil, in particular the case of Laureate International Universities. The research problem was: What factors influence the process of entering a higher education institution in Brazil? and the overall objective is to verify the importance of distances - Culture, Administration, Geographic and Economic - at the entrance of the international Laureate network in Brazil.

As to the research problem is that, based on the findings of this study, all four distances CAGE influence the Laureate entry process in Brazil. Aspects such as cultural difference $(\mathrm{C})$ were the focus of content analysis and evaluate religious beliefs, norms and standards of a society, language and ethnic differences. Differences in language and communication, 
cause costs of information that may not be accurate in translation and result in miscommunication and misinterpretation of information. Countries that share the same language tend to have a turnover three times higher than in countries that do not speak the same language (Ghemawat, 2008).

The administrative distance (A), was also found in the content analysis. The administrative distance involves aspects such as currency and economic model, a member of the same union of countries, eg Commonwealth Countries, or part of a block of free trade as North AmericaFree Trade Area (NAFTA), European Union (EU) and MERCOSUR. There are evidences that this factor was facilitator of the international relations of the countries in the same way that this is an aspect of great impact on the destination country of choice decision process (Andersson and Lundströn, 2007). This distance can be increased with trade barriers such as high import taxes, or rigid standards of quality and product safety. Countries with high levels of corruption and social conflicts suffer a negative impact on economic development (Ghemawat, 2008).

The geographic distance $(\mathrm{G})$ was also the focus of the content analysis. The geographical distance does not refer only by physical distance in kilometers, but the extent and access to the country by water and land, as well as the infrastructure in transport and telecommunications. These aspects also influence the operating cost and speed of transport products. Even communication infrastructure between multinational banks for example, and telephone traffic, can influence the distance factor between countries (Andersson and Lundströn, 2007).

The factor Economic Distance (E), was also a focus of content analysis. This aspect emphasizes that companies that rely on their economies of scale model, standardization and experience, have a greater tendency to move toward markets with similar characteristics (Ghemawat, 2008). When the cost and quality of available resources and even the average income of consumers is far from those found in the home country, companies end up encountering difficulty of success. On the other hand, there are companies that make the distances aspects in its favor, establishing differentiated prices and practices for each market (Andersson and Lundströn, 2007).

As for the main objective of this study has been the cultural distance that includes religious beliefs, norms and standards of a society, language and ethnic differences is revealed as the most important. This can be seen in table 3 (cultural distance) compared with other distances (Tables 4, 5 and 6) because there are more convergent factors to the culture distance when compared to other distances. The cultural aspect of content analysis pointed cultural change with strategic deployments in the internationalization process, the language would not have hindered the process.

Other terms considered culture such as the terms "standards" and "social" did not emerge and therefore did not appear in a convergent manner sample. The terms "standards" and "social" were not relevant to the response of respondents viewed that they did not mention the terms. The contribution of this research to the internationalization of companies, and in this case, higher education, is that the cultural distance overrides in importance to other distances. And the cultural distance, the most relevant factor is cultural changes followed by norms and standards.

So that, for higher education companies trying to enter in Brazil, the main challenge is cultural change, especially in this study, which investigated a US institution with regard to entry in Brazil. As Brazil and USA have very different cultures, to entry in Brazil, language is the main and most important cultural change. Another cultural factor is the religion that imposes norms and standards. It has been the predominant religion in the United States is Protestantism, while in Brazil is Catholicism. These aspects of Christianity have fundamental differences between them concerning differences being won by American companies when operating in Brazil. Among these religious differences that influence the standards and norms, one of the most important is how the acceptance of standards of conduct.

In Brazil, norms, standards and laws are more specific, but the Brazilian is more tolerant to subject to the same, that is, the Brazilian does not follow the norms and standards set by society, their interpretation of what is right or wrong is very flexible. On the other hand, the culture of the United States does not impose so many rules and standards, but when created society tends to follow / accept more, that is, the concept of right and wrong is directly related to the current laws. 


\section{Validity and Reliability}

\subsection{Validity}

This study was validated through triangulation method, which means to collect and analyze data about a particular search using multiple sources and methods, in order to add more quality the validity of the results obtained (Duarte, 2009; Ketokivi, and Choi, 2014; Gerring, 2010). Finally, the collected data were analyzed by CAGE structure proposed by Ghemawat (2008).

Validation of the sample by QSR NVivo 10 for Windows ${ }^{\text {TM }}$ software. One way to validate this research was the categorization of terms and the count (frequency) as they appear in the sample, for this was the chosen terms of similarity with the main terms of the title of this research "Institutions of Entry Process of Higher Education for the Brazil: The Case of Laureate International Universities ". The terms contained in the title of this research were found by QSR NVivo 10 software for Windows TM over 57,000 times in at least 780 sources in the given sample to sample and analyze the study. This implies that the material that makes up the conveniently selected amostrafoi and it is appropriate to clarify the objectives of this research (Lakatos and Marconi, 2010).

Another form of validation of this research was the categorization of terms and the count (frequency) as they appear in the sample, for this was chosen terms by similarity, but this time using the terms found in the general objective and the specific objective of this research: culture; standards; standards; language; confidence; administrative; geographical; economy; and resources.

Another way that we will use for validation of this research is the word cloud. The word cloud organizes and groups the words graphically depending on their frequency. It is a simpler lexical analysis, however graphically quite interesting as it allows the rapid identification of key words in a corpus. These analyzes can be performed from a group of texts concerning a particular subject (corpus) brought together in a single text file. But one must know that the word cloud is not enough to elucidate the problems of this research, however it helps organizing the distribution of vocabulary easily understandable and visually clear.

The vast majority of the terms that the QSR NVivo 10 software for Windows TM found in the sample and represented in the cloud above words are relevant to explain the input process of higher education institutions in Brazil. Some verified words are: education; university; processes; management; education; students and others. And again, according to Lakatos and Marconi (2010), this leads us to the understanding that the material that makes up the sample was properly selected and it is appropriate to clarify the objectives of this research.

\subsection{Reliability}

For the reliability of this research, the interviews were transcribed and then sent to respondents. Some respondents requested minor adjustments or not in the transcripts made first through audio. After receiving the feedback and opinion on agreement of the respondent, the transcripts became part of our sample (Ketokivi and Choi, 2014; Gerring, 2010).

\section{References}

- Alon, I. (2006). Executive insight: evaluating the market size for service franchising in emerging markets. International Journal of Emerging Markets, Vol. 1, No 1, pp. 9-20. Crossref

- Amin, M. A. M., Sanusi, N. A., Kusairi, S., and Abdallah, Z. M. (2014). Inverse relationship of financial risk and performance in commercial banks in Tanzania. Investment Management and Financial Innovationas, Vol. 11, Issue 4, pp. 279-291.

- Investment Management and Financial Innovationas, Vol. 11, Issue 4, pp. 279-291.

- Andersson, C., and Lundström, F. (2007). Evaluating Emerging Markets. 2007.42 f (Master Thesis -Uppsala University).

- Baalbaki, I. B., and Malhotra, N. K. (1993). Marketing management bases for international market segmentation: an alternate look at the standardization/customization debate. International Marketing Review, Vol. 10, Issue 1, pp. 1944. Crossref

- Bardin, L. (2011). Análise de conteúdo. 3. reimp. Lisboa: Ediçoes, 70 
- Bauer, M. W.; and Aarts, B. (2002) A construção do corpus: um princípio para a coleta de dados qualitativos. In: Bauer, M.; Gaskell, G. (org.). Pesquisa qualitativa com texto, imagem e som. Petrópolis: Vozes.

- Berry, H., Guillén, M. F., and Zhou, N. (2010). An institutional approach to cross-national distance. Journal of International Business Studies, Vol. 41, Issue 9, pp. 1460-1480. Crossref

- Chao, M. C. H., and Kumar, V. (2010). The impact of institutional distance on the international diversity-performance relationship. Journal of World Business, Vol. 45, Issue 1, pp. 93-103. Crossref

- Campbell, J. T., Eden, L., and Miller, S. R. (2012). Multinationals and corporate social responsibility in host countries: Does distance matter? Journal of International Business Studies, Vol. 43, Issue 1, pp. 84-106. Crossref

- Cavusgil, S. T., Knight, G., and Riesenberger, J. R. (2010). Negócios Internacionais: estratégia, gestão e novas realidades. São Paulo: Pearson Education.

- Cesar, A. M. R. V. C. (2005). Método do Estudo de Caso (Case studies) ou Método do Caso (Teaching Cases)? Uma análise dos dois métodos no Ensino e Pesquisa em Administração. REMAC Revista Eletrônica Mackenzie de Casos, São Paulo-Brasil, Vol. 1, Issue 1, pp. 1-22.

- Creswell, J. W., and Miller, D. L. (2000). Determining validity in qualitative inquiry. Theory into practice, Vol. 39, Issue 3, pp. 124-130. Crossref

- Creswell, J. W. (2010). Projeto de pesquisa métodos qualitativo, quantitativo e misto. In Projeto de pesquisa métodos qualitativo, quantitativo e misto. Porto Alegre: Artmed.

- De Mooij, M. (2004), Consumer Behavior and Culture: Consequences for Global Marketing and Advertising. Thousand Oaks, CA: Sage Publications.

- Drogendijk, R., and Slangen, A. (2006). Hofstede, Schwartz, or managerial perceptions? The effects of different cultural distance measures on establishment mode choices by multinational enterprises. International business review, Vol. 15, Issue 4, pp. 361-380. Crossref

- Dow, D., and Karunaratna, A. (2006). Developing a multidimensional instrument to measure psychic distance stimuli. Journal of International Business Studies, Vol. 37, Issue 5, pp. 578-602. Crossref

- Duarte, T. (2009). A possibilidade da investigação a 3: reflexões sobre triangulação (metodológica). CIES e-working, Portugal, 60.

- Eisenhardt, K. M. (1989). Building theories from case study research. Academy of management review, Vol. 14, Issue 4, pp. 532-550.

- Gerring, J. (2010). Causal mechanisms: Yes, but.... Comparative Political Studies, Vol. 43, Issue 11, pp. 1499-1526. Crossref

- Ghemawat, P. (2001). Distance still matters. Harvard business review, Vol. 79, Issue 8, pp. 137-147.

- Ghemawat, P. (2008). Reconceptualizing international strategy and organization. Strategic Organization, Vol. 6, Issue 2, pp. 195-206. Crossref

- Golafshani, N. (2003). Understanding reliability and validity in qualitative research. The qualitative report, Vol. 8, Issue 4, pp. 597-606.

- Goetzmann, W. N., and Jorion, P. (1999). Re-emerging markets. Journal of Financial and Quantitative Analysis, Vol. 34, Issue 1, pp. 1-32. Crossref

- Guha, S., Rastogi, R., and Shim, K. (2001). Cure: an efficient clustering algorithm for large databases. Information Systems, Vol. 26, Issue 1, pp. 35-58. Crossref

- Håkanson, L., and Ambos, B. (2010). The antecedents of psychic distance. Journal of

- International Management, Vol. 16, Issue 3, pp. 195-210.

- Harris, S., and Wheeler, C. (2005). Entrepreneurs' relationships for internationalization: functions, origins and strategies. International business review, Vol. 14, Issue 2, pp. 187-207. Crossref

- Hayhoe, R. (1989). China's universities and the open door. ME Sharpe.

- Hennart, J. F. (2010). Transaction cost theory and international business. Journal of Retailing, Vol. 86, Issue 3, pp. 257-269. Crossref

- Hitt, M. A., Dacin, M. T., Levitas, E., Arregle, J. L., and Borza, A. (2000). Partner selection in emerging and developed market contexts: Resource-based and organizational learning perspectives. Academy of Management journal, Vol. 43, Issue 3, pp. 449-467. Crossref

- Hofstede, G. (1980). Motivation, leadership, and organization: do American theories apply abroad? Organizational dynamics, Vol. 9, Issue 1, pp. 42-63. Crossref

- Hofstede, G. H., and Hofstede, G. (2001). Culture's consequences: Comparing values, behaviors, institutions and organizations across nations. Thousands Oaks CA: Sage Publications. 
- Inep - Instituto Nacional de Estudos e Pesquisas ... (2014). Retrieved September 26, 2014, from http://www.inep.gov.br/download/superior/censo/2009/sinopse_da_educacao_superior_2009.xls

- Jain, S. C. (1989). Standardization of international marketing strategy: some research hypotheses. The Journal of Marketing, Vol. 53, Issue 1, pp. 70-79. Crossref

- Ketokivi, M., and Choi, T. (2014). Renaissance of case research as a scientific method. Journal of Operations Management, Vol. 32, Issue 5, pp. 232-240. Crossref

- Khanna, T., and Palepu, K. (1997). Why focused strategies may be wrong for emerging markets. Harvard business review, Vol. 75, Issue 4, pp. 41-48.

- Khanna, T., Palepu, K., and Sinha, J. (2005). Strategies that fit emerging markets. Harvard Business Review, Vol. 83, Issue 6, pp. 63-74.

- Kogut, B., and Singh, H. (1988). The effect of national culture on the choice of entry mode. Journal of international business studies, Vol. 19, Issue 3, pp. 411-432. Crossref

- Kostova, T., and Roth, K. (2002). Adoption of an organizational practice by subsidiaries of multinational corporations: Institutional and relational effects. Academy of management journal, Vol. 54, Issue 1, pp. $215-233$. Crossref

- Kostova, T., Roth, K., and Dacin, M. T. (2008). Institutional theory in the study of multinational corporations: A critique and new directions. Academy of management review, Vol. 33, Issue 4, pp. 994-1006. Crossref

- KPMG. (2014). Pesquisa de Fusões e Aquisições - 2o. Trimestre de 2014. Retrieved September 26, 2015, from https://www.kpmg.com/BR/PT/Estudos_Analises/artigosepublicacoes/Documents/Fusoes e Aquisicoes/2014/FA-2trim2014.pdf

- Kuo, C. L., and Fang, W. C. (2009). Psychic distance and FDI location choice: Empirical examination of Taiwanese firms in China. Asia Pacific Management Review, Vol. 14, Issue 1, pp. 85-106.

- Kvale, S. (2008). Doing interviews. Thousands Oaks CA: Sage Publications.

- Lakatos, E. M., and Marconi, M. D. A. 2010. Fundamentos de metodologia científica. São Paulo: Atlas Editora.

- Lamy, P. (2006) "The Doha Development Agenda: Sweet Dreams or Slip Slidin

- Away?" Speech delivered at the Institute for International Economics 17th of February. http://www.iie.com/publications/papers/paper.cfm?ResearchID=598 2006-11-10

- Laureate, E. (2015). About Laureate. Retrieved September 26, 2016, from http://www.laureate.net/AboutLaureate

- Merrilees, B. (2014). International Franchising: Evolution of Theory and Practice. Journal of Marketing Channels, Vol. 21, Issue 3, pp. 133-142. Crossref

- Miller, K. D. (1992). A framework for integrated risk management in international business. Journal of international business studies, Vol. 23, Issue 2, pp. 311-331. Crossref

- Mojah, T. (2004). Policy responses on global transformation by African higher education system in Paul T. African Universities in the twenty-first century. Darka, CODESRIA, 21-41.

- O'Reilly, A. J. (1988). Establishing successful joint ventures in developing nations: A CEO's perspective. Columbia Journal of World Business, Vol. 23, Issue 1, pp. 65-71.

- Olabuénaga, J. I. R., and Uribarri, M. A. I. (1989). La descodificación de la vida cotidiana:: métodos de investigación cualitativa. Bilbao: Universidad de Deusto; Deustuko Unibertsitatea.

- Peak, M. H. (1992). Will Africa open for business? Management Review, Vol. 81, Issue 6, pp. 47.

- Prahalad, C. K., and Hart, S. L. (2002). The Fortune at the Bottom of the Pyramid. Strategy+ Business Magazine, Vol. 26, Issue 1, pp. 2-14.

- Rabiee, F. (2004). Focus-group interview and data analysis. Proceedings of the nutrition society, Vol. 63, Issue 4, pp. 655-660. Crossref

- Rebouças, D. D. P. O. (2005). Sistemas, Organização and Métodos. Uma abordagem gerencial. São Paulo: Atlas.

- Root, F. R. (1994). Entry strategies for international markets. San Francisco:Jossey-Bass.

- Schwartz, S. H. (1994). Are there universal aspects in the structure and contents of human values? Journal of social issues, Vol. 50, Issue 4, pp. 19-45. Crossref

- Schwandt, T. A. (2000). Three epistemological stances for qualitative inquiry: Interpretivism, hermeneutics, and social constructionism. Handbook of qualitative research, $2^{\text {nd }}$ Edition, pp. 189-213.

- Shenkar, O. (2001). Cultural distance revisited: Towards a more rigorous conceptualization and measurement of cultural differences. Journal of international business studies, Vol. 32, Issue 3, pp. 519-535. Crossref

- Sheth, J. N. (2011). Impact of emerging markets on marketing: Rethinking existing perspectives and practices. Journal of Marketing, Vol. 75, Issue 4, pp. 166-182. Crossref 
- Strijbos, J. W., Martens, R. L., Prins, F. J., and Jochems, W. M. (2006). Content analysis: What are they talking about?. Computers and Education, Vol. 46, Issue 1, pp. 29-48. Crossref

- Suri, H. (2011). Purposeful sampling in qualitative research synthesis.Qualitative Research Journal, Vol. 11, Issue 2, pp. 63-75. Crossref

- Swanborn, P. (2010). Case study research: what, why and how? Thousands Oaks CA: Sage.

- Tuli, K. R., Kohli, A. K., and Bharadwaj, S. G. (2007). Rethinking customer solutions: From product bundles to relational processes. Journal of Marketing, Vol. 71, Issue 3, pp. 1-17. Crossref

- Vachani, S. (1991). Distinguishing between related and unrelated international geographic diversification: A comprehensive measure of global diversification. Journal of International Business Studies, Vol. 22, Issue 2, pp. 307322. Crossref

- $\mathrm{Xu}, \mathrm{D}$., and Shenkar, O. (2002). Note: Institutional distance and the multinational enterprise. Academy of Management review, Vol. 27, Issue 4, pp. 608-618.

- Watt, D. (2007). On becoming a qualitative researcher: The value of reflexivity. The Qualitative Report, Vol. 12, Issue 1, pp. 82-101.

- Welch, L., and Luostarinen, S. R. (1988). Internalization: Evoluation of a Concept. Journal of General Management, Vol. 14, Issue 2, pp. 34-55. Crossref

- Wilson, D. and Purushothaman, R. (2003), "Dreaming with BRICs: The Path to 2050," Global Economics Paper Issue 99.

- Zogby. (2014, June 09). The University of the Future: The Laureate/Zogby Global

- Students Poll. Retrieved September 26, 2014, from http://zogbyanalytics.com/ 